\title{
Para-formal commerce: a cartography of public space in the Brazil-Uruguay border
}

\author{
O comércio para-formal: uma cartografia no espaço público da fronteira \\ Brasil-Uruguai
}

\author{
Eduardo Rocha[a] [i] , Lorena Maia Resende[a]
}

[a] Universidade Federal de Pelotas (UFPel), Faculdade de Arquitetura e Urbanismo (FAUrb), Programa de Pósgraduação em Arquitetura e Urbanismo (PROGRAU), Pelotas, RS, Brasil

How to cite: Rocha, E., \& Resende, L. M. (2019). Para-formal commerce: a cartography of public space in the BrazilUruguay border. urbe. Revista Brasileira de Gestão Urbana, 11, e20180087. https://doi.org/10.1590/21753369.011.002.A010

\section{Abstract}

This article presents a research experience carried out between 2014 and 2017 in six twin-cities in the Brazil-Uruguay border. The study aimed to identify and analyze para-formal commerce scenes that occupy public spaces in contemporaneity, in order to contribute to future intervention projects. We developed maps, photographs and cartographic writings based on the methodology of sensitive urban cartography and travelling pedagogy; from analysis of the three main plans found - place, equipment and body - to the assemblage with concepts of the philosophy of difference. As results, we highlight that in the Brazil-Uruguay border, para-formal commerce densifies near free-shops, intensifies near the border lines in dry borders, spreads over cities in wet borders, and is mostly found in sidewalks. Para-formal within formal is the most notable category; para-formal carries cultural identities in the products sold. This activity possesses some accommodation in the occupation of public space, and para-formal is a wellfunded activity at the border, which is not very volatile in relation to the economy.

Keywords: Border. Twin-cities. Para-formal. Public space. Urban cartography.

\section{Resumo}

O artigo apresenta os resultados da experiência de pesquisa realizada entre os anos de 2014 e 2017 em seis cidades-gêmeas da fronteira Brasil-Uruguai, com o objetivo de identificar e analisar as cenas comerciais para-formais que ocupam os espaços públicos na contemporaneidade, bem como contribuir com futuros projetos de intervenção. Com base na metodologia da cartografia urbana sensível e da pedagogia da viagem, foram produzidos mapas, fotografias e escritas cartográficas; foram analisados ainda os três principais planos encontrados, o lugar, o equipamento e o corpo, a partir dos conceitos da filosofia da diferença. Como resultados, destaca-se que: o para-formal na fronteira Brasil-Uruguai é visivelmente comercial; densifica-se próximo aos free shops; quando a fronteira é seca, intensifica-se na linha de fronteira; quando a fronteira é molhada, espalha-se pela cidade; a maioria dos para-formais se encontra nas calçadas; que o para-formal no formal é a categoria que mais se destaca; o para-formal

ER is doctor in Architecture, master degree in Education, post-graduate in Cultural Heritage, architect and urbanist, e-mail:

LMR is master student in Architecture and Urbanism, architect and urbanist, e-mail: lorenamilitao@gmail.com 
carrega identidades culturais no produto vendido; a atividade possui certa acomodação na ocupação do espaço público; e o para-formal na fronteira é uma atividade consolidada, não possuindo tanta volatilidade em relação à economia.

Palavras-chave: Fronteira. Cidades-gêmeas. Para-formal. Espaço público. Cartografia urbana.

\section{Introduction}

This essay results from a research carried out from 2014 to 20171, developed by the Urbanism Lab at the Architecture and Urbanism School of Federal University of Pelotas (UFPEL), Brazil, involving para-formal in public spaces of twin-cities (Chuí-Chuy; Jaguarão-Rio Branco; Aceguá-Acegua; Santana do Livramento-Rivera; Quaraí-Artigas and Barra do Quaraí-Bella Unión) of the Brazil-Uruguay border. Para-formal is a boundary concept, between formal and informal, created by the Argentine group Gris Público Americano, which discusses the several forms of appropriation of public spaces in contemporary cities. Such activities resist to traditional urban logics and produce "ecological discontinuous spaces" (GPA, 2010) in an indetermination zone. The investigation of para-formal scenes is a decolonization process of fixed and totalizing categories of hegemonic European theories, which are not able to read the diversity and liveliness (chaos) found in Latin American cities.

In previous researchers in Latin American cities, para-formal was found in many situations (Allemand et al., 2014). Each city, in its own peculiarities, reveals this other urban, which coexists with the real, known city. Especially in city centers, in the animation of flows and encounters, such events resist, disturb, interact and show the gaps of urbanity, at the same time as they (re)create themselves and change need into opportunity, fresh, unexpected. The study and reflection about urban design theories and multiple uses of public spaces approximate to such investigations.

In this essay, para-formal are all the human activities that occupy public space but are not part of the city's physical urban design. They configure urban scenes, a concept developed by sociologist Ana Clara Torres Ribeiro (2009) that alerts to the importance of lived social experience. Scenes that register the interconnection between social and urban agents in new "ways of making" - as emphasized by philosopher Certeau (1994) -, that even in places of impositions and rules make it possible to arise creativity and allow unpredictable actions. As examples, we can highlight these activities: commerce (street vendors etc.); culture (street actors, street musicians etc.); housing (homeless people); leisure (sit by the sidewalks, have a chimarrão etc.); among others.

In the last decade, many researchers have sought to map and determine uses for public space; where we walk, where we stop to rest, and which places are indicated to certain activities in cities. On the other hand, many other researchers have been cartographing subjective movements in the city, making interviews and urban writings, discovering specificities of lifestyles that do not match the urban design that is offered. However, few works take a risk in urban gaps, in this grey area of uncertainty, spaces with no clear limit between public and private that make new urban plans. This way, there is a blank regarding coexistence of such information, of how to overlap physical urban and lived urban, bringing up questions like: which things unite and separate formal and informal city in the Brazil-Uruguay border? How does integration of heterogeneous collectives in the same environment happen and what are their limits? What ethical and technical implications of these scenes are called para-formal? What does para-formal tell us and how does it contribute to launch new projects for the city? And how can a project support, following what already exists and resists?

\footnotetext{
${ }^{1}$ Research funded by the Brazilian National Council for Scientific and Technological Development (CNPQ), under supervision of Doctor Eduardo Rocha (PROGRAU-UFPel) and with collaboration of extension scholars Humberto Levy de Souza and Laís Dellinghausen Portela, undergraduate students at Architecture and Urbanism School at Federal University of Pelotas (UFPEL), Brazil.
} 
Interest in studying the international border is justified by the potentials of the border place, which at once separates and unites two countries, of daily life with the other in their difference and similarity, of the know-how to deal with cultural, economic and political barriers. It is a place of integration and conflict where one doubts about crossing the line or not. It is in this mutation and subversion zone, in this territorial rip, that para-formal reveals its most active and singular ways. It is also justified by the geographic proximity of this research group and the development of other works by the Urbanism Lab in the border region?2.

This study aimed to identify para-formals in the Brazil-Uruguay border and what they reveal about appropriations of public space in contemporaneity; and to analyze implications and contributions of these scenes to both academic reference and to future intervention projects. Thus, we used the methodology of sensitive urban cartography, which calls upon the procedure of travelling pedagogy to structure the research into before the trip, during the trip and after the trip; as moments that are distinguished in space and time, corresponding to a preparation, a plunge and reflections about the experience of para-formal in the Brazil-Uruguay border. As a result, we produced maps, photographs and cartographic writings from the analysis of the three main plans found - the place (public space); the equipment (material tools); and the body (the animated agent) - in assemblage with concepts of the philosophy of difference 3 .

By the end of the process, we highlight as our main findings: (a) para-formal, in the Brazil-Uruguay border, is notably commercial; (b) para-formal densifies mostly around free-shops; (c) when the border is dry, para-formal intensifies in border lines; (d) when the border is wet, para-formal spreads over cities; (e) most para-formals are found in sidewalks, in a dispute for space with pedestrians; (f) paraformal within formal is the most notable category in every border city; (g) para-formal carries cultural identities in the product they sell; (h) para-formal activity, in the border, presents some accommodation, some passivity regarding occupation of public space, in the coexistence of para-formal and formal, among nationalities and even in the mix of languages; (i) in the border, para-formal is a well-funded, historical activity, that is not very volatile in relation to the economy; (j) twin-cities are so integrated that it was not possible to categorize para-formal according to differences of country, only between dry and wet borders.

\section{The Brazil-Uruguay border}

The Brazil-Uruguay border presents an extension of 1,069 km, of which $749 \mathrm{~km}$ go along river courses, and the reamining $320 \mathrm{~km}$ are dry borders without geographic barriers (Pucci, 2010). On the

\footnotetext{
${ }^{2}$ The Urbanism Lab (LabUrb) of Architecture and Urbanism School (FAUrb) brings together and supports projects and initiatives that are committed to knowledge about urbanism in its different scales and theme possibilities. It works with teaching, research, extension and administration in an integrate way, based at UFPel's Architecture and Urbanism School. At LabUrb, there are extension projects particularly dedicated to support City Governments' actions of planning and urban design, by strengthening local staff and supporting their autonomy and qualification. Research activities are turned to studies on contemporary urbanism, morphology, modelling, cartography, GIS, geocomputation and visualization resources. There have been several articles published and prizes won. See more at UFPel (2018).

${ }^{3}$ The philosophy of difference comes from the writings by Nietzsche, which "[...] directly helped to shape post-modern discourse." (Peters, 2000, p. 51) [our translation] It is attached to the post-structuralist movement and is "[...] a way of thinking, a philosophy style and a way of writing" (Peters, 2000, p. 28) [our translation], "[...] a thinking movement that embodies different critical forms of practices." (Peters, 2000, p. 29) [our translation] It is a philosophy that builds its thoughts from difference, from what escapes, from cracks, from issued signs. It is about a rupture with the pre-determined structure, with paradigms. It is a way of thinking, a thinking exercise, that bets on a practical philosophy, in which concepts are put into function, into operation, whose reality happens as a social and subjective construction. Philosophers of difference like Foucault, Deleuze, Guattari, Derrida, Agamben, Bauman, among others, are part of a philosophic current whose exponents are Spinoza, Bergson and Nietzsche, a philosophy that is interested in diversity, plurality and singularity, instead of a philosophy based in one universal ideal with singular parts. So, the philosophy of difference is less interested in similarities and identities and more interested in singularity and particularity. This way, comes up a new way of understanding men, the nature, the world, relationships, society, language, values and life.
} 
Brazilian side, the border covers only the state of Rio Grande do Sul, while in Uruguay there are five departments involved: Rocha, Treinta y Tres, Cerro Largo, Rivera and Artigas. In a more effective contact, there are six twin-cities ${ }^{4}$, of which three are dry borders (divided/united by a street or avenue): Chuy-Chuí; Acegua-Aceguá; Rivera-Santana do Livramento; and three wet borders (divided/united by a bridge): Rio Branco-Jaguarão; Artigas-Quaraí and Bella Union-Barra do Quaraí.

The region's geographic conditions and the way the territory has been appropriated by Portuguese and Spanish reflect this spontaneous integration between countries. The Plata River, coveted by expansionist empires, was a gateway to commercial trades from South America to Europe. At first very disputed and conflicted, the region became home of informal business, with a delay regarding urbanization and settlement. The approximation of Jesuit priests contributed to the first settlements and the introduction of livestock and agriculture. Treaties between Crowns along the years (Madrid, El Pardo, San Ildefonso) established diffuse limits, which were not always respected by the people who lived in the Pampa region - later named "gauchos". The San Ildefonso Treaty (1777) left a small strip of no man's land, under no domain of Portugal or Spain, known as Campos Neutrais - neutral fields. This territory attracted many adventurers, smugglers, insurgent natives looking for freedom and diversity. However, aiming to keep order, the Portuguese Crown divided the territory into sesmarias and began a process of occupation and domain with military troops. The same way, the Spanish side, that later became Uruguay, was also starting a process of territory occupation by creating a belt of cities to restrain Brazilian advancements. Among camps and military fortifications, the construction of houses, churches and sheds was the beginning of a more familiar urbanization process. Nonetheless, disputes over power have escalated with the arrival of Portuguese Court in Brazil in 1808. From then on, many other wars have taken place to define territory possession, among which the Cisplatine War, the Farroupilha Revolution, the war against Argentine president Rosa and, during the Republic, the Federalist Revolution (Struminski, 2015).

A peculiar fact is that even in a scenario of several wars, inhabitants of border cities, far from the center of power and political decisions, searched for conciliation and business ties with neighbor towns, as a matter of survival and mutual needs that go beyond pacts and diplomatic agreements. Cities turned united due to proper natural conditions of soil and vegetation, with no difficult barriers like mountains or rivers hard to cross. The Pampa (word with indigenous origin that means "flat region"), which is the name that designates the region's predominant vegetation, composed by large fields covered by grass, is mostly located in the territory of Rio Grande do Sul/Brazil, Uruguay and Argentina. The soil of the border region is soft, with monotonous plains only interrupted by hills in a few points up North. So, it is a natural field of infinite view, where one cannot distinguish one side and the other, except for some artificial physical indication. In the Pampa, the continuous land is a comprehension that is transferred to personal relations.

Thus, the Brazil-Uruguay border presents itself in an integrative co-dependency feature. Both decline and success in one side reflect on the neighbor's behavior, these are "mirror towns". United by geographic landscape and historical background, they flow as political agreements are established. It is a reality that defies laws and urban plans, so, masterplans and urban guidelines must be carried out together, bi-nationally. The imposition of customs transfers their prominence to the first wish of both peoples, to build relationships and coexist peacefully.

In 2005, a Proposal for Restructure of the Border Strip Development Program was created, aiming to establish new strategic policies for subvention of this region, which represents $27 \%$ of Brazilian national territory. The Brazil-Uruguay border, according to this study, fits into two typologies of integration with the neighbor country, the capillary and the synapse. Capillary interaction applies only

\footnotetext{
${ }^{4}$ The concept of twin-cities, according the National Integration Ministry, considers towns that are divided by a border line - an international political landmark - whether it is dry or wet, conurbated or not, with a potential for economic and cultural integration. They can present a continuity of its urban area with the neighbour country. Cities with a population below two thousand inhabitants are not considered twin-cities.
} 
to the Aceguá-Acegua case, in which there is a connection between both sides that only happens locally, with almost no State intervention. These two towns present the lowest population density and a strong rural characteristic, which justifies the State's minimum interference. Whilst synapse happens in all the other twin-cities, with a very strong integration and State investments in infrastructure for communication. In the synapse typology, the Brazil-Uruguay border is divided into spontaneous and promoted interaction. In spontaneous one, cities were formed in a natural way, as it happened in Southern cities; Chuí-Chuy, Jaguarão-Rio Branco and Santana do Livramento-Rivera. Such fact may be due to a great part of this territory being part of the former neutral fields and because they are dry borders, which makes communication easy. Except for Jaguarão-Rio Branco, where there is a 340m long bridge, which is a short distance when compared to other wet borders. Upper North, integration is promoted, as the State interferes since the creation of cities, Quaraí-Artigas and Barra do Quaraí-Bella Union, both with wet borders. In the first one, the international bridge is $750 \mathrm{~m}$ long and in the second one, $670 \mathrm{~m}$. Such distances show a need for infrastructure from the beginning of the integration process (Brasil, 2005).

From the historical, geographic and political panorama of the Brazil-Uruguay border, this research was dedicated to map these twin-cities' central areas, urban areas with a direct contact with the border line. Aiming to identify para-formal focuses, we noticed that they are concentrated and agglomerated in urban centers. Then, cases were registered by wandering the region and by cartography processes.

\section{Sensitive urban cartography}

The data used in this study was collected through the sensitive urban cartography method, which counts on procedures of wandering around in public space and travelling pedagogy. At first, the word cartography suggests the making of maps, a technique of representation of a space or territory, whether it is real or fictional, to communicate information. A map is an attempt to approach reality, an inscription, a registry of an experience for it to be felt in other circumstances or by other subjects. The cartography that we adopt as a method is the assemblage of the philosophy of difference by Deleuze \& Guattari (1997), the study about cartographies of desire by Guattari \& Rolnik (1986) and finally, the cartographic clues from the work by Passos et al. (2009).

Distant from the traditional map, sensitive urban cartography, which is qualitative, privileges investigation process instead of pre-defined answers, territory itself guides clues through rhizomatic paths. It is a dynamic method, with multiple connections, folds and re-folds that follow heterogeneity and complexity of both the border and para-formal. The map that results from this cartography - which can be drawings, photographs, collages, texts, videos, performances - expresses a city that is usually invisible, that cannot be represented without an attentive look to details of daily life, walking experiences, registering urban scenes, sounds, smells and textures.

Travelling pedagogy, a methodological collection procedure that supports cartographic process, can be understood as experience in its two senses. The first one is an actual trip to the place that is being studied, a trip that is known, up to a certain point, since we do know where we are going. Nonetheless, it is also a trip to discover and experiment, towards unpredictable events. Foreigners, nomads, researchers and cartographers are open to apprehend the other. The process of travelling pedagogy can be divided into three moments: before the trip (expectation/anxiety); during the trip (experience); and after the trip (pause/reflection). The first part is when we pack, choose what to take or not, with our thoughts restless because of indetermination. The second stage is experience itself, when our thoughts fly and are constantly crossed by the events. Finally, the third stage is the return, time to unpack and organize memories, calm down our thoughts and allow new assemblages. In this collection, writing is a tool that helps to capture rhizomatic thinking, which comes, goes, returns, in constant movement.

The trip along the whole extension of the Brazil-Uruguay border (Figure 1) started on March 14th, 2016, in a continuous route that established one day for each pair of twin-cities, in a total of six days 
travelling. There were twenty-two travelers, from several knowledge areas: architect-urbanist, engineer, nutritionist, sociologist, artist, geologist, musician, linguist and historian. Each one had their specific research but were all in communication, with interesting reports and different views. One group had the task of identifying and observing para-formal.

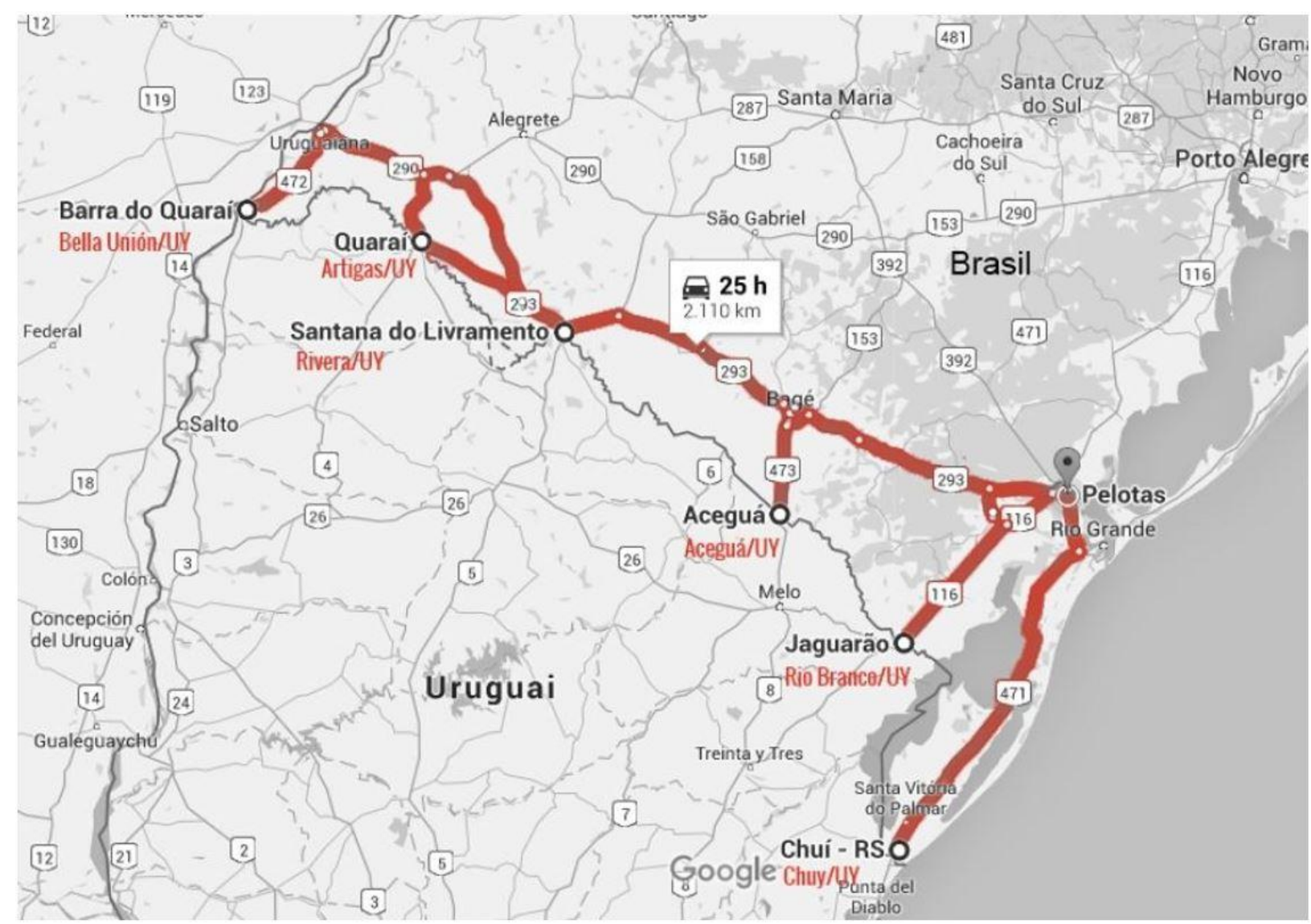

Figure 1 - Route travelled in the Brazil-Uruguay border. Source: Google Maps (2016). Edited by the authors.

We used wandering walks as a method to recognize para-formal. To wander, to loiter, to walk around the city, without departure or arrival points. Urban wandering presents itself as a need to rescue the body of the city in its affective aspects. There has been a certain time when urbanists were focused in organizational, functional, technical issues, leaving the essence and livelihood of streets aside. Corrupted by the acceleration of the capital, there was no space for mistakes, for the physical, bodily experience, to get out of the paper and feel the urban poetics. This procedure was used since Baudelaire's efforts, with the figure of the flâneur exploring streets of a Paris that was transformed by Haussmann between 1853 and 1870, until modern derives as proposed by the Situationists, with a critical bias regarding modern urbanism.

While wandering, we went inside events of the border cities and allowed ourselves to take detours as a part of the process. The dynamics of the border itself presented in a variety of ways within the urban center, thus, to limit priorities to our looks was a challenge. In our hands, a travelling journal was the device that kept/registered the voice of the restless thoughts in the wandering process. Composed by blank pages and basic maps, the journal turned into a precious tool, in which it is possible to revive and extract sensations from each crossing and each roaming invited by subjectivity.

Another tool was the camera, as a mean of capturing moments, situations and landscapes that allows understanding the cartographer views, in situations in which there was a need to register. The body resisted, reacted over other citizen-bodies or other urban-bodies. Sometimes, it was not possible to understand the need, only the desire to register, as if the camera had its own life and demanded to be 
clicked. This way, it was possible to make para-formal activities visible and identify them in different performances in public space in the Brazil-Uruguay border.

Lastly, sensitive urban cartography is built from analyzing all the materials collected through travelling pedagogy and wandering walks. Such analysis happens through assemblage with philosophy of difference. From this moment on, the methodology plays its role and allows reflecting and presenting results and conclusions about discoveries presented by para-formal in the border.

\section{Para-formal in/from the border}

Cartography results reveal heterogeneous and complex urban scenes. Each one of them is formed by plans (place, equipment and body), located in a certain border group (shallow or deep) and, finally, can be analyzed from assemblages with the philosophy of difference (especially in a dialogue with authors as Deleuze, Guattari and Agamben).

\section{The plans: place, equipment and body}

The act of snipping urban scenes originates plans. We refer to the plan of immanence of philosophy, presented by Deleuze \& Guattari (1993) in the text "What is philosophy?", as a space dedicated to wavering and assemblage of concepts. It is a plan of constant movement that expels transcendence in its rigor. It constitutes the image of thought. Urban scene is composed by chaos and lack of order, due to the multiplicity of crossings. This way, to deal with and to accept chaos, one needs to cut it and choose plans that configure the thought into fragments of possible worlds. In the wandering process, many scenes have been registered through photographs - a crystallization of an instant, transformed in image. More than 1.500 photographs have been taken in the twelve twin-cities. When looking attentively to the material that was collected, three main plans configured every scene: place, equipment and body (Figure 2).
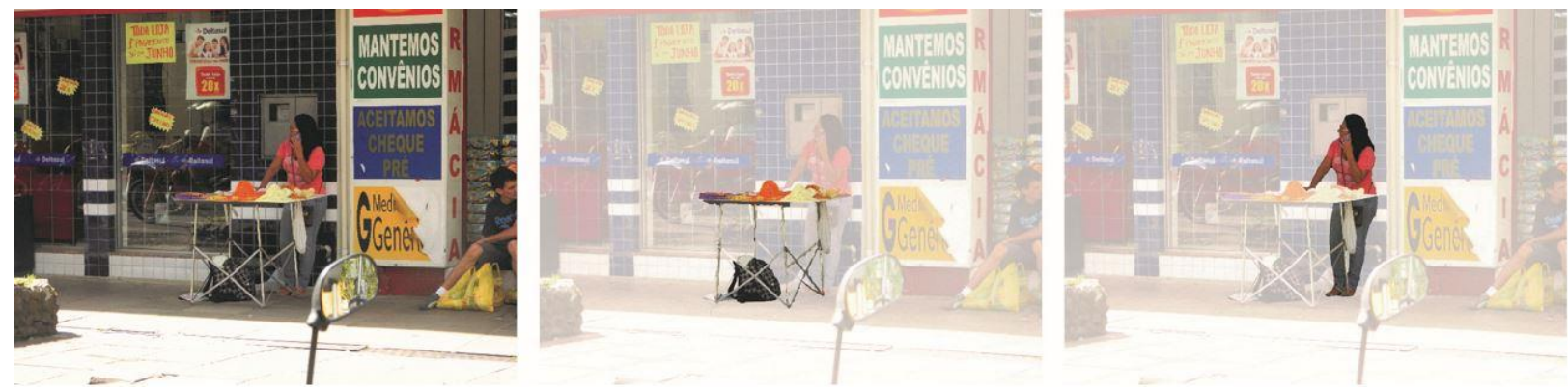

Figure 2 - Para-formal plans found in the city of Santana do Livramento/Brazil. From left to right: place, equipment and body. Source: Research files (2017).

The place is the region where para-formal can be found, in this case, public space. Traditionally, public space is conceived as a part of urban territory to which access is universal. However, it does not approach only the collective accessibility issue, it is also about appropriation, whether it is social, economic or political. From a morphological point of view, architect and urbanist Patricia Rodríguez Alomá (2013) understands public spaces as urban voids conformed by lines of buildings, usually filled with green areas and urban furniture that make information, locomotion, pauses in displacements and permanence of people in the environment easier. Besides this, public space also provides the infrastructure that is needed for cities to work, like supports for the road, electricity, hydrosanitary and waste networks and other technical services under State supervision and maintenance. Gehl \& Gemzoe (2002) analyze public space through a functionalist view, established by modern urbanism, with intent to organize and order urban 
structure. These authors classify public space in three functional categories: necessary, optional and social activities, in which urban design is in co-relation with the different ways to use it.

Many other professionals from different knowledge areas, such as sociology, philosophy and geography, also discuss the concept and implications of public space. However, the closest idea to this research is the one by geographer Angelo Serpa (2004), who sees public space, from a contemporary and critical point of view, as a space of political action, proper for it to happen. Since Industrial Revolution, the global scenario is going through changes, especially in what concerns building and living in cities. Due to separation of social and economic classes; to the conception of exceeding product and consequently of profit; to capitalist economic relations and new political conceptions, cities became great centers of consumption, "[...] an ideology of happiness through consumption, the joy of urbanism adapted to its new mission" (Lefebvre, 1991, p. 32) As technologies advanced, physical distances shortened, while social distances grew. All of that has an impact over public space, which has lately become a stage of "invisible privatizations" - such as the gentrification process - with none or little contact with effectively social practices.

Nonetheless, at the same time, it is in public space that urban ruptures happen; it is a place of explicit social segregation and a field of manifestations. The street that is home for commercial advertising is the same one that is home for denunciation of corruption, power abuse and fight for equality. The same happens to activities in public parks/squares, which sometimes sell a culture of the marketing and sometimes a culture of street artists. Public space represents a dichotomic life, a threshold between democracy and despotism. Regarding twin-cities, when they are conurbated, the definition of public space is even more diffuse, with places that one does not know in which country they are and which jurisdiction to respect.

Para-formal in the Brazil-Uruguay border was observed in streets, sidewalks, corners and squares (Figure 3). We also considered weather conditions and adaptations due to it. Since the trip along the border happened during summer, with a very hot stuffy weather, para-formal preferred shaded places, under marquees, improvising parasols or under trees. In some cases, they used some building façade, sidewalk floor, vegetation and even urban furniture (benches, trash cans, light poles) to place their tools (Figure 4).

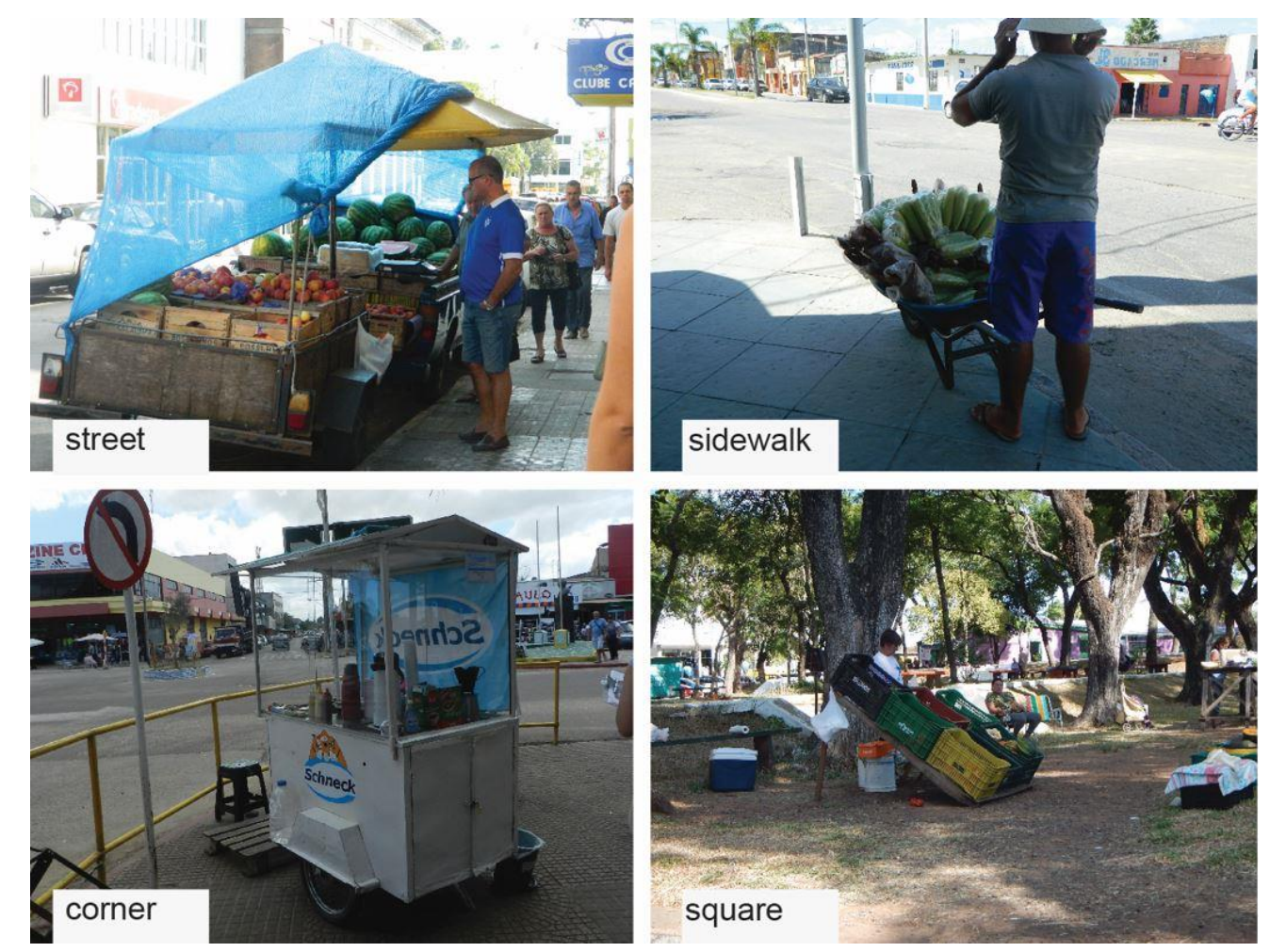

Figure 3 - Para-formal places in the border. Street: Santana do Livramento/BR. Sidewalk: Jaguarão/ BR. Corner: Chuy/UY. Square: Santana do Livramento/BR. Source: Research files (2017). 

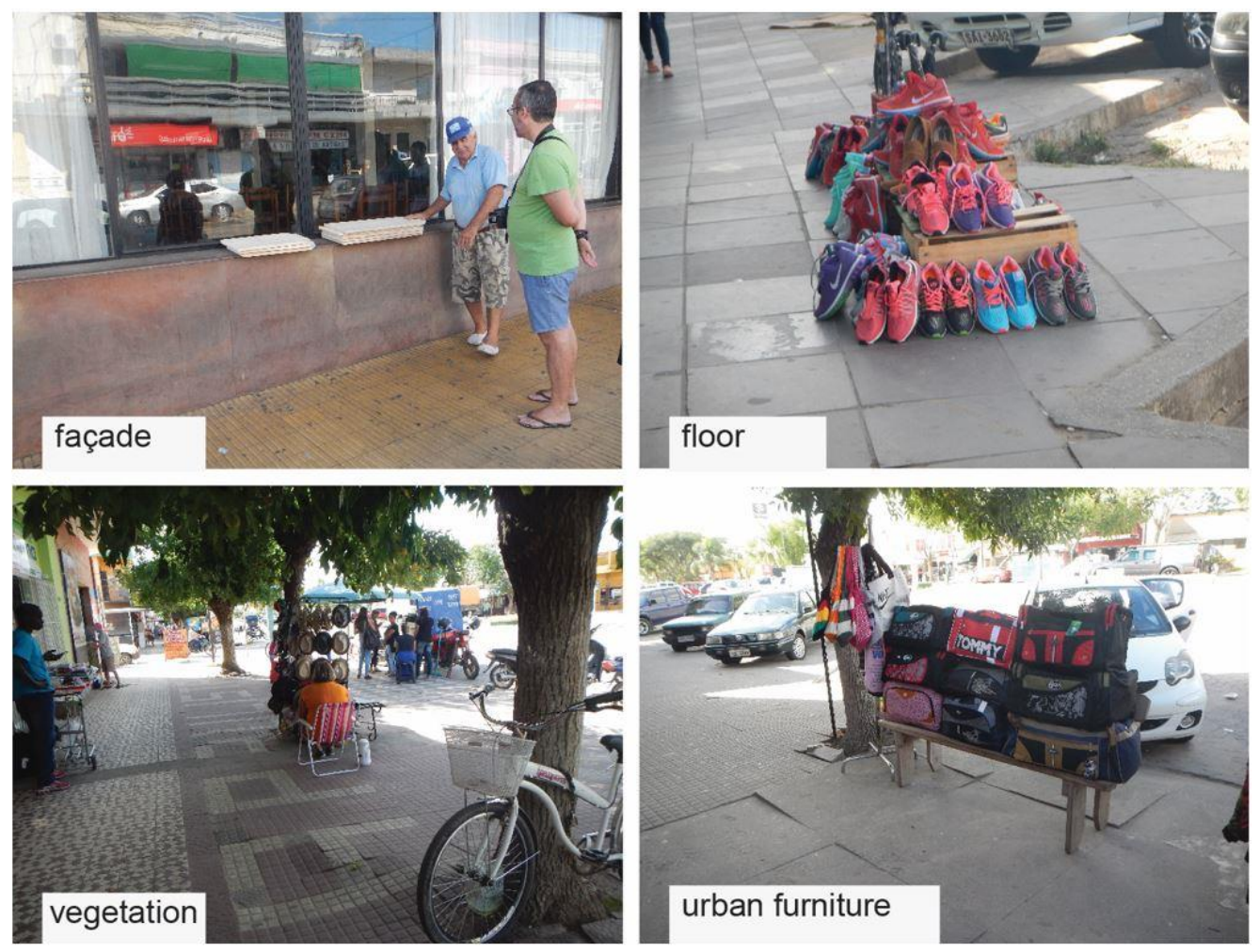

Figure 4 - Appropriation of public space by para-formal. Façade: Artigas/UY. Floor: Chuí/BR. Vegetation: Chuy/UY. Urban furniture: Chuy/UY. Source: Research files (2017).

Of all the material collected in the twelve border cities, the place with the highest number and the para-formal's preference is the sidewalk. Fighting for space with pedestrians, para-formal draws attention for the proximity between products and clients. In the cities of Chuí and Chuy, whole sidewalks of entire blocks are filled, working as improvised shop windows. The floor as a support for products was also the most observed option, maybe because installation is easy and does not interfere so much as in façades or urban furniture. Another common activity in these cities is the intense presence of para-formal within formal (Figure 5), which is a category that happens because of the extension of formal activities - fixed stores - on sidewalks. Bars and restaurants use sidewalks to place tables and chairs; clothing stores put mannequins close to their façades; toy stores and hardware shops also show samples of products in front of their buildings. In a certain way, para-formal within formal wishes to draw the clients' attention and show their products the same way as their para-formal competitors, this may be an excuse for advancing over sidewalks. 

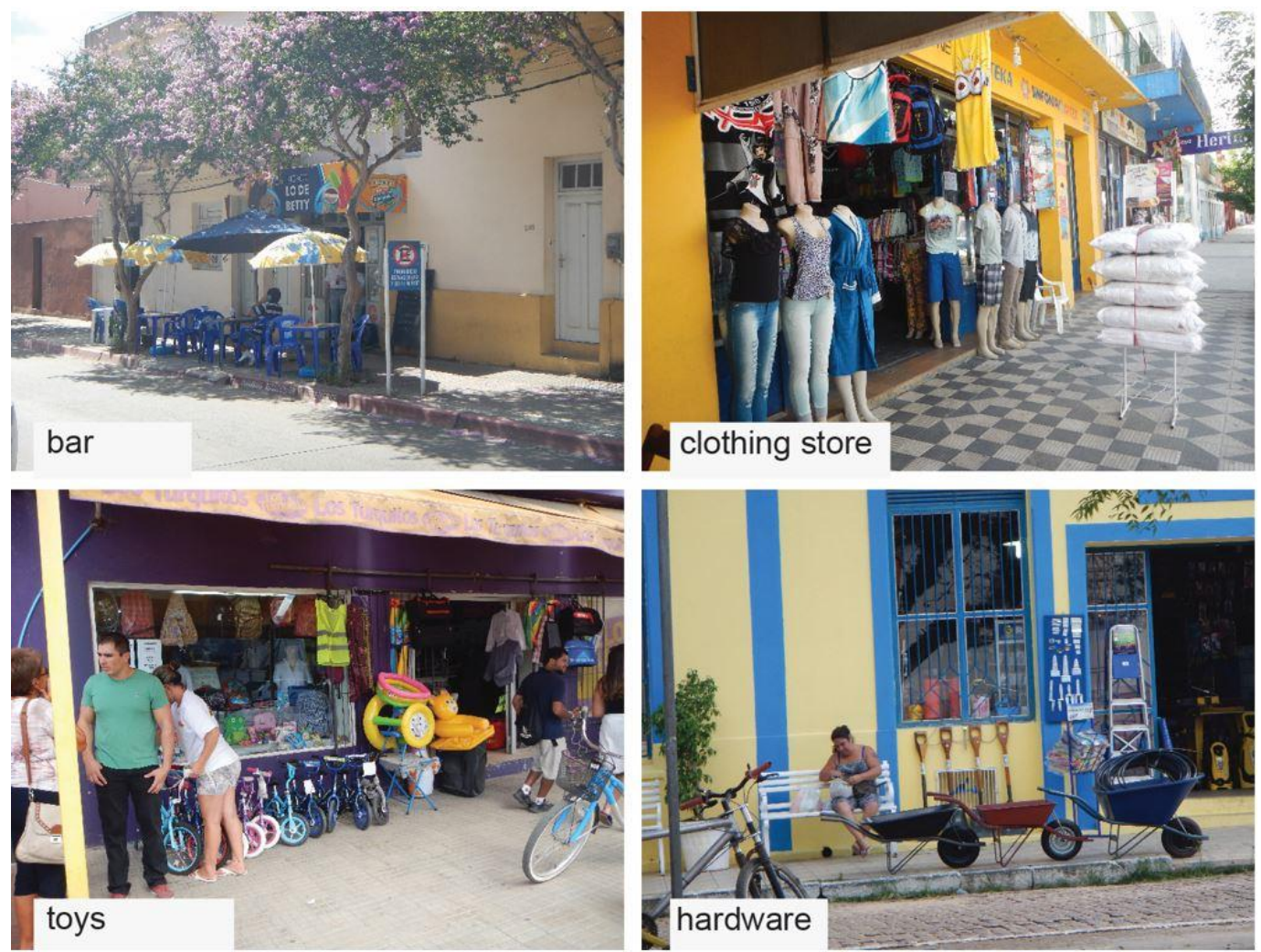

Figure 5 - Registries of para-formal within formal. Bar: Artigas/UY. Clothing store: Chuí/BR. Toys: Rio Branco/UY. Hardware: Jaguarão/BR. Source: Research files (2017).

As for equipment, which is the structure that supports and exposes the material being sold, we classify it into four categories: mobility, size, material and installations. Mobility is divided into fixed, mobile or itinerant. The great occurrence found in this category was mobile. Some equipment had wheels (popcorn or sweet carts, handcarts with clothes); some were small wood or metal structures easy to carry (electronics, watches or glasses stands). Itinerant equipment was also found, usually with small products, carried in the body (hammocks and car upholstery).

As for size, medium ones prevailed, with equipment that usually have wheels, parasols and are easy to move. Regarding materials, they were quite diverse, including wood, metal, plastic, sailcloth and paperboard. However, most cases resulted in a mix of metal structure with wood supports. In what concerns installations, very few para-formals had some electric or hydraulic points, which is understandable since most are in constant mobility. Meanwhile, para-formal within formal usually has an electricity point, since it is very close to a fixed store, which makes it easier. In a few cases of big fixed para-formals, such as trailers that sell food, there were electric and hydraulic installations.

It was not possible to notice any correlation of equipment with different cities and countries, as in all of them products were presented with diversity and creativity. The same way equipment occupy the space, disturb displacements and cause visual pollution, they cheer the city up, share unusual scenes and favors communication.

Finally, in what concerns the body, animated agent, human being, we verified the amount of bodies and their position in space. The body figure, that sometimes plays the main role and sometimes plays a supporting role, makes up the last plan of urban scenes that we analyzed. Most of the times the body is individual and able to accomplish every function, from bargain to product reposition. The position of the body was inconstant, some moved more, some had a beach chair close to the products and remained seated. Gender and age also varied, making it impossible to obtain an acceptable result with big differences that would allow inferring a stereotype. Young people, adults, seniors, men and women were seen, all of them with skills to perform that activity. 
A curiosity that we observed in the para-formal body in the border was that in many registries bodies do not show. They are away, sometimes on the other side of the street or around the corner, observing the products and attentive to any movement, but unconcerned about possible thefts. Even in para-formal within formal, with products standing outside of the store and occupying great extensions, the responsible person is inside, apart from external events. Maybe because it is a routine and historical activity, vendors have acquired a certain familiarity and keep collective watching ties, through which they all take care of each other's products.

\section{The shallow border and the deep border}

The findings of this study, from experiencing the six twin-cities in the Brazil-Uruguay border, show clear evidence of commercial para-formal. However, amongst these cities there are some interesting peculiarities regarding movement and action of such activities. For the purpose of classifying events in a more elucidative manner, the group qualified borders into shallow and deep and also took into account different border architectures, for example, the customs. The shallow and deep classification approaches the skin concept by Deleuze (1974) and Paul Valéry (1960), thinking of skin as a sensibility organ, of the touch, as well as of its porous character, thinking of the existence of a surface that communicates with a deeper layer. Juhani Pallasmaa (2011), in his work "The eyes of the skin. Architecture and the senses", observes the importance of peripheral look at and experience of places, in contraposition to the focused look of a hegemonic view. He praises touch as an extension of all other senses: "[...] our contact with the world takes place at the boundary line of the self through specialized parts of our enveloping membrane" (Pallasmaa, 2011, p. 10). From that, after the contact with the border cities, we named shallow border those twin-cities divided/united by a street and/or square, or so to say, dry borders. Shallow means of little depth, a contact surface, which does not infer less complexity or incompleteness, on the opposite hand, it means it is a surface composed by some layers of immediate and untimely contact. It is shallow because it is easy to cross. Meanwhile, deep border includes those twin-cities divided/united by a bridge, the wet borders. The same way, deep border refers to a superposition of several layers with a more distant but not less intense contact. Deepness is not related to intensity, but with displacements of inter-relations. Deep because it is difficult to cross. The border is formed by a dense body; there are always porous layers that are more or less connected.

The fact, regardless of the kind of border, is that para-formal commerce is strong and marked. One of the possible reasons for the predominance of commercial (there was not any case of artistic exhibition or housing) can be justified by the fact that it is a zone of attractive commercial tourism. Every Uruguayan twin-city has free-shops (tax-free, duty-free), which sell imported products with little or no tax for foreigners. With such facilities, Brazilians head to international borders looking for products with high quality and low price. This economic appeal agitates both cities. Brazilian side does not have free shops yet (recently, there has been speculation on a possible opening for this activity), on the other hand, they qualify the hotel and gastronomy networks, to host tourists and raise profits. It is a kind of commerce that depends on variations of the Dollar exchange rates, so there are times of the year with a higher flow of consumers than others, but there is always some action.

Other activities are made easier because of the border, such as smuggling and embezzlement. Historian Suzana Souza (1996) states that such commercial exchange practices, in the Brazil-Uruguay border, have been the palladium of moments of war and territory disputes, a matter of survival. She emphasizes that during the process of limiting borders there were political and administrative obstacles, but in economy, countries searched for integration. The border zone, far from the country's political centers both in Brazil and in Uruguay, saw in the economic alliance with the neighbor an opportunity to stay alive and active in the market. This way, border inhabitants have some flexibility to choose which country is more favorable for their business. 
Such scenario is seen as a fertile ground for several families and people who find themselves in a vulnerable economic situation. With low initial cost, para-formal sees a possibility to succeed by selling products in the border region, both for the high flow of people, of tourists, all year round, and for the poor surveillance.

Another finding relates to physical proximity of these para-formals to free-shops. The more linear and intense the Uruguayan imported products stores are, the more intense para-formal activities are. In shallow borders, as represented in Figure 6, it is possible to notice that free-shops lines formed in Uruguayan cities are followed by another line, of adjacent para-formals. Since it is a shallow border, easy to cross, there are entire corridors of para-formals, which are made easier by the Pampa topography and ground - a flat ground with an infinite edge. Urban layout also influences such moves. In the case of Acegua-UY/Aceguá-BR, there is a large void between limiting avenues and because of that, in the Brazilian side para-formal is more spread, since the connection with free-shops is weaker. In Rivera-UY/Santana do Livramento-BR, the territory's limit is in a square, in which several para-formals are spread, but other lines of this activity form towards free-shops. In Chuy-UY/Chuí-BR the case is more visible, with free shops in the Uruguayan side and para-formals that follow them. It is important to point out that there are para-formals in the interior of each country, but they are more observed in the border line, in the territorial rip.

In deep borders, also represented in Figure 6, free shops are spread around cities; they do not fill lines of whole blocks like in shallow borders. Consequently, para-formal also follows this logic and is spread around too. Both in Quaraí-BR/Artigas-UY and in Barra do Quaraí-BR/Bella Únion-UY, displacement between twin-cities is larger, there is no direct contact with free-shops in the Brazilian case and this way, para-formal is located in several strategic points - urban centers, squares and other places with a higher flow of people. The same way, in the Uruguayan side some para-formals are closer to free-shops but were also seen further, in squares and commercial centers. The Jaguarão-BR/Rio Branco-UY case is peculiar, since the bridge that unites/separates the two countries is $340 \mathrm{~m}$ long, which is a short distance, we can even see the neighbor country with the naked eye. In this case, in the Uruguayan city of Rio Branco, free shops are concentrated in the city entrance, with entire streets dedicated to this kind of store, creating an intense line. For this reason, in the city of Jaguarão, in Brazilian side, para-formal is concentrated close to the bridge, where they form whole corridors of the most varied products. There are some cases spread in both cities' interiors. These examples prove the connection of para-formal and free-shops. 


\section{SHALLOW BORDER}

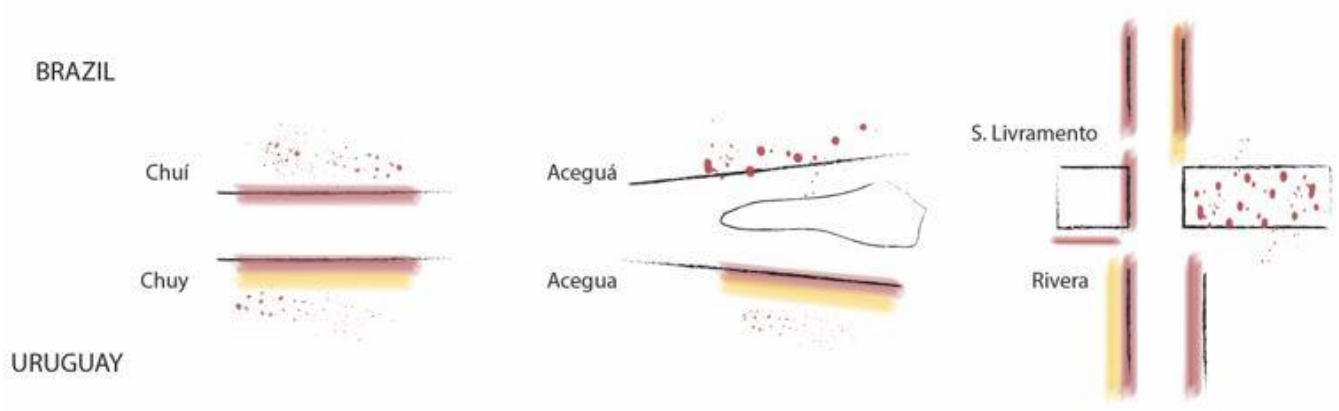

\section{DEEP BORDER}
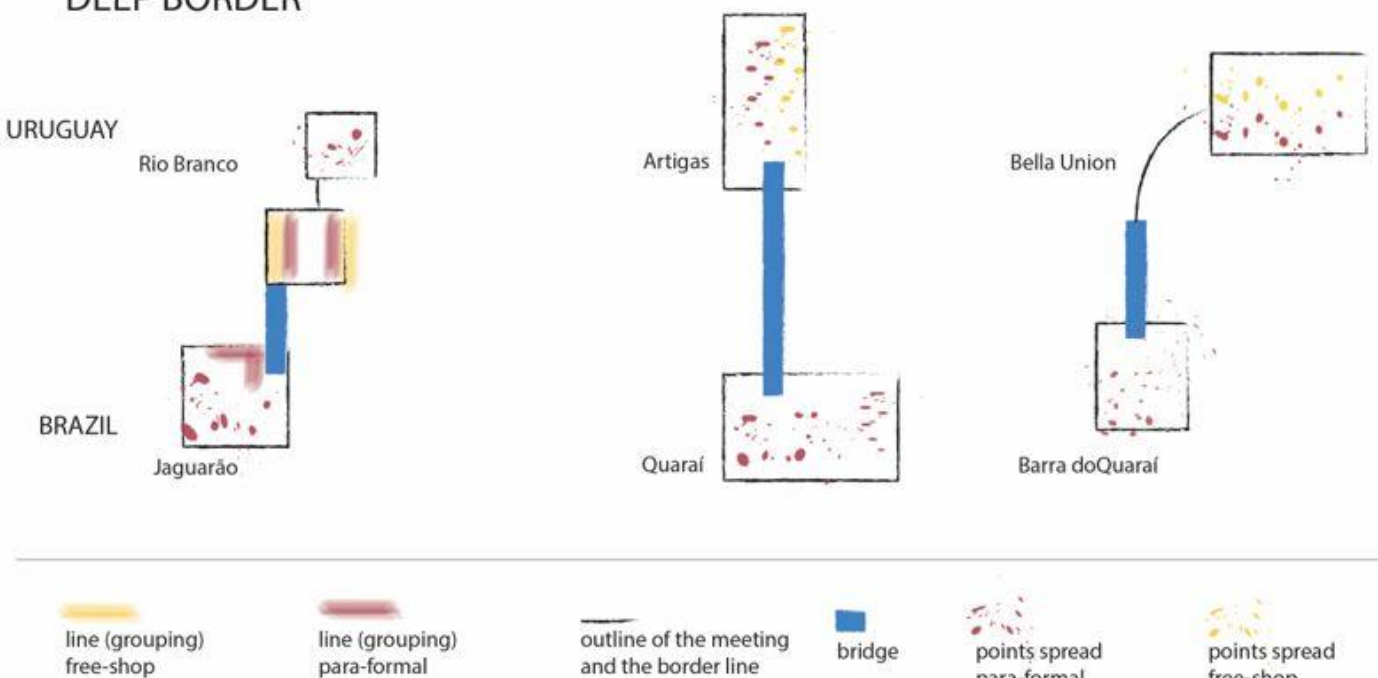

outline of the meeting
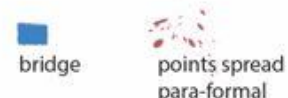

points spread

Figure 6 - Shallow and deep borders analysis. Source: Research files (2018).

It is notable that cities that are part of the shallow border have a more visible para-formal commerce, while in deep border perception of this activity is attenuated, except only for JaguarãoBR/Rio Branco-UY, due to physical and visual proximity.

\section{Assemblages with the philosophy of difference: bare life and sovereign power}

An assemblage, from the deleuze-guattarian philosophy, covers the multiplicity of heterogeneous components. The research group formed by architects and urbanists feels attracted to these philosophers' contributions, putting up new assemblages that reveal other study perspectives. The work "Homo Sacer: Sovereign power and bare life", by Italian philosopher Giorgio Agamben (2002), is close to the relationship of para-formal and contemporary public space. Agamben alerts to the capture of human life (for the Greeks, zoé - natural life) by western law and politics, which became a "naturalized" and not very discussed matter in contemporaneity. Politics is transformed into biopolitics (Greek word bíos - political life), or so to say, zoé is included into power domination. However, human life exists within politics as a potential threat of installing pure bare life (an expression by Walter Benjamin), or referring to archaic roman figure of Homo Sacer.

Any person or circumstance that disturbs the State order can suffer with the suspension of their right to live, creating a state of exception. Homo sacer represents the one that is included through exclusion and excluded in an inclusive way, or so to say, the State that has the duty of protection is 
suspending rights. A ban, bandit, abandonment life. For Agamben, the word ban means both exclusion and freedom, in the sense that one does not belong anywhere, thus is loose, free to make any decision. In a denser analysis, one finds that the "ban" represents a force of attraction and repulsion that ties together two (coexisting) opposite poles of bare life and sovereign power, "[...] we must learn to recognize this structure in the political relations and public spaces in which we still live" (Agamben, 2002, p. 117). If something or someone was abandoned, it is because at first, they did belong somewhere. Nonetheless, even when they are excluded, they are still somehow connected with their origins, although they do not belong to any specific place.

At this point, border para-formal can correlate with the ban, for they are, in a certain way, abandoned in a place of indetermination. Para-formal is precisely this force that at times gathers and at times repulses discussions between sovereign power and bare life. Para-formal body represents the homo sacer, whose legal rights of merchants have been suspended in order to live as a freed ban, but who is in constant danger of facing customs, having their products arrested and in more severe cases, of being punished in jails, when sovereign power smashes bare life and subjects to reclusion.

This research is extoling this figure, who resists to the imposed order and shows human reality in its unequal face of a world of privileges. Some bans from certain social groups are more controlled and persecuted than others. Those guidelines are determined by sovereign power and its target can vary according to individual interests, showing us how vulnerable and uncertain human life is. The border region is a zone of commercial interests and political conflicts, rules of what is acceptable or not are variable. Today, a street vendor can cross the border and sell his product, but tomorrow barriers can be imposed.

Just like Foucault (1988, p. 104) states that "[...] where there is power, there is resistance", bare life can be seen as a resistance to sovereign power, a shout of contrariness, expressed by creativity and new "ways of making". Assemblages allow another view of this border trade, which feeds itself of another border, between formal and informal. The importance of this natural and controversial movement that at once animates and disturbs public space. Para-formal in the border is a portrait of the capacity human beings have to adapt to adverse situations and be a tool for denunciation.

\section{Conclusions}

Wandering walks, along with the development of sensitive urban cartography, allowed this research to go beyond the crossing of international bridges and get to another parallel world, of subjective experience. An attentive and floating look at the six twin-cities of the Brazil-Uruguay border exposed the reality of para-formal in public space. We identified prevalence of commercial para-formal presented in three main plans: place, equipment and body. In unusual ways, this activity fills sidewalks and draws attention for the diversity of equipment and products.

We also identified that para-formal's densification in the border is directly connected to the location of free-shops, where there are more people circulating. Shallow borders presented the biggest group of para-formal, for they are easy to cross and circulate and free-shops are linear. Meanwhile, deep borders lose this group power of the para-formal as they spread over specific points of the city, also following imported products stores. Para-formal in the Brazil-Uruguay border reveals a spontaneous appropriation of public space, with activities that fill empty spaces of urban design and make them agitated dynamic spaces. They also reveal a strong integration between countries, once it is not possible to distinguish main characteristics of one side or the other, they represented an ensemble. Countries know each other so well that the border lines give a feeling of representing only one place. Even language changes, with Spanish and Portuguese mixing, colliding, exchanging and returning in another form, the portunhol. The currency exchange of Real and Peso is also easy, as both are used for selling and buying.

Para-formal also carries cultural identity, that can be perceived in the products sold, such as electric thermal jars, cuias and bombas for the traditional chimarrão, which is a typical tea drink shared by both nationalities. The same way, one finds socks, woolen sweaters, sheepskin blankets, hats, caps and other 
clothes used in the region's rigorous winter. Food like panchos, chivitos and barbecue are also present in both sides. Those are goods that represent both gaucho and Uruguayan lifestyles.

Contemporary embraces multiplicity and heterogeneity and thus requires the researcher to be careful when choosing a study object and in the relations that this object establishes with society, to avoid common sense. We approach the city as a place of encounter of object (objective) and subject (subjective), then, we constantly deal with quantitative and qualitative data, between which there is no hierarchy but a complementation. The superposition of these maps points to ruptures, resistances, potentials that support planning cities in a more consistent way, avoiding segregation with gentrification and public space privatization processes that usually approach the city as merchandise. This way, this research proposes a new way of looking at cities, it proposes to look at them from close and from inside, in addition to implicitly criticize some traditional methods of observation, from far and from outside, that only see the city as tabula rasa, in a two-dimension plan. The world we live in lacks city life experience, walking around the city and discovering what is peculiar in each one of its corners.

Quality of urban design is attached to the perception of the real city. Para-formal is a consolidated, historical activity in the border that is not volatile in relation to the economy, but in relation to political power, which can interfere or not in the permanence of such kind of commerce. These are resistant cities that exchange both subjective and collective experiences among them. Para-formal shows abandonment and reflects freedom of choice, teaching us to deal with embarrassing situations. It is necessary to follow para-formal's development up, to accommodate it in public space through quality solutions for urban design, which can assure liveliness and plurality, giving public space a politicalsocial feature again.

\section{References}

Agamben, G. (2002). Homo Sacer: o poder soberano e a vida nua I. Belo Horizonte: Editora UFMG.

Alomá, P. R. (2013). El espacio público, ese protagonista de la ciudad. ArchDaily Brasil. Retrieved in 2018, March 4, from https://www.archdaily.com.br/br/01-162164/o-espaco-publico-esse-protagonista-da-cidade

Allemand, D. S., Rocha, E., \& Pinho, R. B. (2014). Discovering the para-formal city: controversies and mediations in public space. V!RUS, 10. Retrieved in 2018, March 4, from

http://www.nomads.usp.br/virus/virus10/?sec=4\&item=1\&lang=en

Brasil. Ministério da Integração Nacional. (2005). Programa de Desenvolvimento da Faixa de Fronteira. Brasília: Ministério da Integração Nacional. Retrieved in 2018, March 11, from http://www.retis.igeo.ufrj.br/wpcontent/uploads/2005-livro-PDFF.pdf

Certeau, M. (1994). A invenção do cotidiano. Petrópolis: Vozes.

Deleuze, G. (1974). A lógica do sentido. São Paulo: Perspectiva.

Deleuze, G., \& Guattari, F. (1993). O que é a Filosofia? São Paulo: Editora 34.

Deleuze, G., \& Guattari, F. (1997). Mil Platôs: capitalismo e esquizofrenia (Vol. 4). São Paulo: Editora 34.

Foucault, M. (1988). História da sexualidade: a vontade de saber. Rio de Janeiro: Graal.

Gehl, J., \& Gemzoe, L. (2002). Novos espaços urbanos. Barcelona: Gustavo Gili.

Gris Público Americano - GPA. (2010). Para-formal: ecologias urbanas. Buenos Aires: Bisman Ediciones; CCEBA Apuntes.

Google Maps. (2016). Brazil-Uruguay border. Retrieved in 2016, April 10, from

https://www.google.com.br/maps/@-31.7727569,-56.2040869,7.5z

Guattari, F., \& Rolnik, S. (1986). Micropolítica: cartografias do desejo. Petrópolis: Vozes. 
Lefebvre, H. (1991). O direito à cidade. São Paulo: Editora Moraes.

Pallasmaa, J. (2011). Os olhos da pele: a arquitetura e os sentidos. Porto Alegre: Bookman.

Passos, E., Kastrup, V., \& Escóssia, L. (Eds.). (2009). Pistas do método da cartografia: pesquisa-intervenção e produção de subjetividade. Porto Alegre: Sulina.

Peters, M. (2000). Pós-estruturalismo e filosofia da diferença: uma introdução. Belo Horizonte: Autêntica.

Pucci, A. S. (2010). O estatuto da fronteira Brasil-Uruguai. Brasília: Fundação Alexandre Gusmão.

Ribeiro, A. C. T. (2009). Cartografia da ação social: região latino-americana e novo desenvolvimento urbano. In: H. Poggiese, \& T. T. C. Egler (Eds.), Otro desarrollo urbano: ciudad incluyente, justicia social y gestión democrática. Buenos Aires: CLACSO.

Serpa, A. (2004). Espaço público e acessibilidade: notas para uma abordagem geográfica. GEOUSP: Espaço e Tempo, 15, 21-37.

Souza, S. B. (1996). Os caminhos e os homens do contrabando. In: I. R. Castello (Ed.), Práticas de Integração nas fronteiras: temas para o Mercosul. Porto Alegre: Editora UFRGS.

Struminski, E. (2015). Brasil e Uruguai, fronteiras e limites. Ilhéus: Editus.

Universidade Federal de Pelotas - UFPel. (2018). Cidade + Contemporaneidade. Pelotas. Retrieved in 2018, March 4, from http://cmaiscufpel.wixsite.com/cmaisc

Valéry, P. (1960). L’idée fixe. In: P. Valéry, Oeuvres complètes (Vol. 2). Paris: La Pléiade.

Editor: Rodrigo José Firmino

Received: May 04, 2018

Approved: Sept. 13, 2018 